\title{
Effect of progesterone on nitric oxide/cyclic guanosine monophosphate signaling and contraction in gastric smooth muscle cells
}

\author{
OTHMAN A. AL-SHBOUL ${ }^{1}$, AYMAN G. MUSTAFA ${ }^{2,4}$, AMAL ABU OMAR $^{2}$, AHMED N. AL-DWAIRI $^{1}$, \\ MOHAMMAD A. ALQUDAH ${ }^{1}$, MONA S. NAZZAL ${ }^{1}$, MAHMOUD A. ALFAQIH $^{1}$ and RAMI A. AL-HADER ${ }^{3}$ \\ Departments of ${ }^{1}$ Physiology and Biochemistry, and ${ }^{2}$ Anatomy, Faculty of Medicine, Jordan University of Science and \\ Technology, Irbid 22110; ${ }^{3}$ Department of Physiology and Biochemistry, Princess Basma Teaching Hospital, \\ Faculty of Medicine, Jordan University of Science and Technology, Irbid 21110, Jordan
}

Received July 13, 2018; Accepted October 10, 2018

DOI: $10.3892 /$ br.2018.1161

\begin{abstract}
Previous studies have shown that progesterone could inhibit muscle contraction in various sites of the gastrointestinal tract. The underlying mechanisms responsible for these inhibitory effects of progesterone are not fully known. The aim of the current study was to investigate the effect of progesterone on the nitric oxide (NO)/cyclic guanosine monophosphate (cGMP) pathway and muscle contraction in the stomach. Single gastric smooth muscle cells from female Sprague-Dawley rats were used. The expression of progesterone receptor (PR) mRNA was analyzed by reverse transcription polymerase chain reaction. NO and cGMP levels were measured via specific ELISAs. Acetylcholine (ACh)-induced contraction of single gastric muscle cells preincubated with progesterone was measured via scanning micrometry in the presence or absence of the NO synthase inhibitor, $\mathrm{N} \omega$-Nitro-L-arginine (L-NNA), or guanylyl cyclase inhibitor, $1 \mathrm{H}$-[1,2,4]Oxadiazolo[4,3-a]quinoxalin-1-one (ODQ), and expressed as percent shortening from resting cell length. PR expression was detected in the stomach muscle cells. Progesterone inhibited ACh-induced gastric muscle cell contraction. Furthermore, progesterone increased NO and cGMP levels in single gastric muscle cells. Most notably, pre-incubation of muscle cells with either L-NNA or ODQ abolished the inhibitory action of progesterone on muscle contraction. These present observations suggest that progesterone promotes muscle cell relaxation in the stomach potentially via the NO/cGMP pathway.
\end{abstract}

Correspondence to: Dr Othman A. Al-Shboul, Department of Physiology and Biochemistry, Faculty of Medicine, Jordan University of Science and Technology, P.O. Box 3030, Irbid 22110, Jordan

E-mail: oashboul@just.edu.jo

Present address: ${ }^{4}$ Department of Basic Medical Sciences, College of Medicine, Qatar University, Doha, Qatar

Key words: contraction, progesterone, smooth muscle, nitic oxide/cyclic guanosine monophosphate pathway, stomach

\section{Introduction}

Progesterone is a steroid hormone that has been identified to inhibit contraction of smooth muscle in various regions in the gastrointestinal (GI) tract (1-5). It has been indicated that changes in the levels of steroid hormones in the plasma, including of estrogen and progesterone, leads to GI motility disturbances in pregnant women. Specifically, pregnancy, which is characterized by high plasma steroid hormonal levels, has been associated with decreased gallbladder contractility (6), lowered esophageal sphincter pressure (7), reduced gastric emptying (8-10), and reduced small intestinal (11) and colonic transit (9). However, the exact molecular mechanisms for such steroid hormone-associated GI motility disorders remain poorly understood.

Progesterone can impair the actions of agonists that are $\mathrm{G}$ protein receptor dependent. In the context of muscle function, progesterone has been observed to downregulate $\mathrm{G}_{\mathrm{i}}$ and $\mathrm{G} \alpha_{\mathrm{q}}$ proteins, which mediate contraction, and upregulate $\mathrm{G} \alpha_{\mathrm{s}}$ proteins, which mediate relaxation $(1,2)$. Furthermore, it has been suggested that progesterone may lead to activation of tyrosine kinases (12) and mitogen-activated protein kinases (13), and inhibition of membrane transport systems (14). Researchers have previously identified that progesterone inhibited agonist-induced contraction in dissociated colonic muscle cells, mediated by $\mathrm{Ca}^{2+}$ release from intracellular stores (15). The same group later reported that progesterone decreased the basal colon motility in vivo by altering the levels and actions of prostaglandins (16). Our group previously demonstrated that progesterone may rapidly affect the contractile activity of isolated gastric smooth muscle cells (GSMCs) in rats via inhibition of the Rho kinase II pathway (17). Physiologically, smooth muscle is an important component of the GI tract, and maintaining its normal contractile behavior is essential for proper GI functions. Smooth muscle relaxation is initiated by targeting dephosphorylation of the $20-\mathrm{kDa}$ regulatory myosin light chain $\left(\mathrm{MLC}_{20}\right)$. Most agents cause relaxation by stimulating the production of cyclic adenosine monophosphate (cAMP) or cyclic guanosine monophosphate (cGMP) (18). cAMP-activated protein kinase $\mathrm{A}$ and 
cGMP-activated protein kinase $\mathrm{G}$ are the main enzymes that induce relaxation in smooth muscle (19). Nitric oxide (NO) induces the production of cGMP from guanosine triphosphate via activating the soluble guanylyl cyclase (sGC) (20). cGMP is then rapidly degraded by cGMP-specific phosphodiesterases (PDEs) (21).

Although numerous studies $(9,15,16)$ have examined the effect of progesterone on GI smooth muscle, its effect on the gastric NO/cGMP pathway and thus muscle contraction has not yet been investigated to our knowledge. Therefore, the present study was designed to investigate the action of progesterone on the NO/cGMP pathway in smooth muscle cells of the stomach. Insights into the molecular basis of progesterone effects on gastric smooth muscle function would be an important step for improved understanding of certain GI motility disturbances and complaints that complicate pregnancy, and of certain female functional disorders such as female colonic inertia, colonic slow transit and delayed gastric emptying.

\section{Materials and methods}

Materials. A DC protein assay kit for measuring protein concentration was obtained from Bio-Rad Laboratories, Inc. (cat. no. 500-0116; Hercules, CA, USA). A cGMP colorimetric ELISA kit (cat. no. STA-505) was obtained from Cell BioLabs, Inc., San Diego, CA, USA. 1H-[1,2,4] Oxadiazolo[4,3-a]quinoxalin-1-one (ODQ; cat. no. ab120022) and $\mathrm{N} \omega$-Nitro-L-arginine (L-NNA; cat. no. ab141312) were obtained from Abcam (Cambridge, UK). A 500- $\mu \mathrm{m}$ Nitex mesh was purchased from Sefar AG, Thal, Switzerland. All remaining chemicals were from Sigma-Aldrich (Merck KGaA, Darmstadt, Germany). Stock solution of progesterone was prepared in $100 \%$ ethanol. Stock solutions of ODQ and L-NNA were prepared in dimethylsulfoxide. The final concentration of ethanol and DMSO was $1 \%(\mathrm{v} / \mathrm{v})$.

Isolation of GSMCs. All experimental protocols were approved by the Animal Care and Use Committee at Jordan University of Science and Technology, Irbid, Jordan and all procedures were conducted in accordance with the guidelines set by this committee. A total of 20 female Sprague-Dawley rats (12 weeks of age; $250-300 \mathrm{~g}$ ) were provided by the animal house of the Jordan University of Science and Technology. They were housed under standardized conditions (temperature $20-22^{\circ} \mathrm{C}$, humidity $50-60 \%$ and a 12 -h light/dark cycle) and allowed free access to food and tap water throughout the experiments. Animals were euthanized by inhalation of $\mathrm{CO}_{2}$ for at least $5 \mathrm{~min}$. For confirmation of euthanasia an incision was made through the chest cavity with a scalpel blade. Following euthanasia the stomach was immediately excised. Smooth muscle cells were isolated from the stomachs of the rats by sequential enzymatic digestion, filtration and centrifugation as described previously $(22,23)$. In brief, strips of muscle from the stomach were dissected and incubated at $31^{\circ} \mathrm{C}$ for $30 \mathrm{~min}$ in 4-(2-hydroxyethyl)-1-piperazineethanesulfonic acid (HEPES) buffer composed of: $120 \mathrm{mM} \mathrm{NaCl}, 4 \mathrm{mM} \mathrm{KCl}$, $2.0 \mathrm{mM} \mathrm{CaCl}_{2}, 2.6 \mathrm{mM} \mathrm{KH}_{2} \mathrm{PO}_{4}, 0.6 \mathrm{mM} \mathrm{MgCl} 2,25 \mathrm{mM}$ HEPES, $14 \mathrm{mM}$ glucose, 2.1\% Eagle's essential amino acid mixture, $0.1 \%$ collagenase and $0.01 \%$ soybean trypsin inhibitor with $\mathrm{pH}$ adjusted to 7.4. The partly digested strips were washed twice with $50 \mathrm{ml}$ enzyme-free HEPES medium and the muscle cells were allowed to disperse spontaneously for $30 \mathrm{~min}$. The cells were harvested by filtration through $500-\mu \mathrm{m}$ Nitex mesh and centrifuged twice at $350 \mathrm{xg}$ for $10 \mathrm{~min}$ at $4^{\circ} \mathrm{C}$ to eliminate broken cells and organelles. Cells were maintained at room temperature and experiments were performed within $2-3 \mathrm{~h}$ of cell collection.

Measurement of contraction in dispersed GSMCs. Contraction of isolated muscle cells was measured by scanning micrometry as described previously $(23,24)$. In brief, aliquots of cell suspension from 10 of the rats each containing $\sim 10^{4}$ cells $/ \mathrm{ml}$ were added to HEPES medium and randomly distributed into either control or progesterone-treated groups. Cells in the treatment groups were incubated at room temperature for 10 min with progesterone $(1 \mu \mathrm{M})$, progesterone and ODQ (GC inhibitor; $1 \mu \mathrm{M}$ ), or progesterone and L-NNA (NO synthase inhibitor; $1 \mu \mathrm{M})$. A progesterone concentration of $1 \mu \mathrm{M}$ was effective in our previous research (17); in addition, after reviewing the progesterone dose response curve reported in other studies $(25,26)$, the concentration of $1 \mu \mathrm{M}$ occurred in the middle of the curve and was thus deemed suitable. Cells were then stimulated for 10 min with acetylcholine $(\mathrm{ACh}$; $0.1 \mu \mathrm{M})$ in the presence or absence of treatment agents at room temperature. Cells in the control groups were treated with or without ACh $(0.1 \mu \mathrm{M})$. Cells in the control group not treated with ACh (treated only with distilled water) were considered as the negative control and used for measuring the basal cell length. The reaction was terminated with acrolein $(0.1 \%$ final concentration). The cells were viewed using a $\times 10$ or $\times 20$ objective of an inverted Nikon TMS-f microscope (Nikon Corporation, Tokyo, Japan), and cell images were acquired using a Canon digital camera (Canon Inc., Tokyo, Japan) and ImageJ acquisition software (version 1.45s; National Institutes of Health, Bethesda, MA, USA). The length of 50 muscle cells treated with the contractile agent $(\mathrm{ACh})$ was measured at random by scanning micrometry $(23,24)$. This was then compared with the length of untreated cells. Contraction was expressed as the percentage decrease of mean cell length, as compared with the control group.

Measurement of smooth muscle NO and cGMP. In the remaining rats $(\mathrm{n}=10)$, the concentration of $\mathrm{NO}$ in smooth muscle samples was indirectly measured by determining nitrite and nitrate levels utilizing an $\mathrm{NO}\left(\mathrm{NO}_{2}{ }^{-} / \mathrm{NO}_{3}{ }^{-}\right)$assay kit (cat. no. 23479; Sigma-Aldrich; Merck KGaA) following the manufacturer's protocol. The level of cGMP in smooth muscle samples was also measured using the cGMP ELISA kit according to the manufacturer's protocol. NO and cGMP levels were measured in cells treated with progesterone, and in cells not treated with progesterone which represented the basal levels.

Detection of progesterone receptor $(P R)$ expression by reverse transcription-polymerase chain reaction (RT-PCR). RT-PCR was performed on cDNA samples synthesized from total RNA isolated from stomach muscle cells and PCR conditions were optimized via preliminary runs with a BioRad T100 PCR Thermal Cycler (Bio-Rad Laboratories, Inc.). Total RNA was isolated from freshly dispersed smooth 


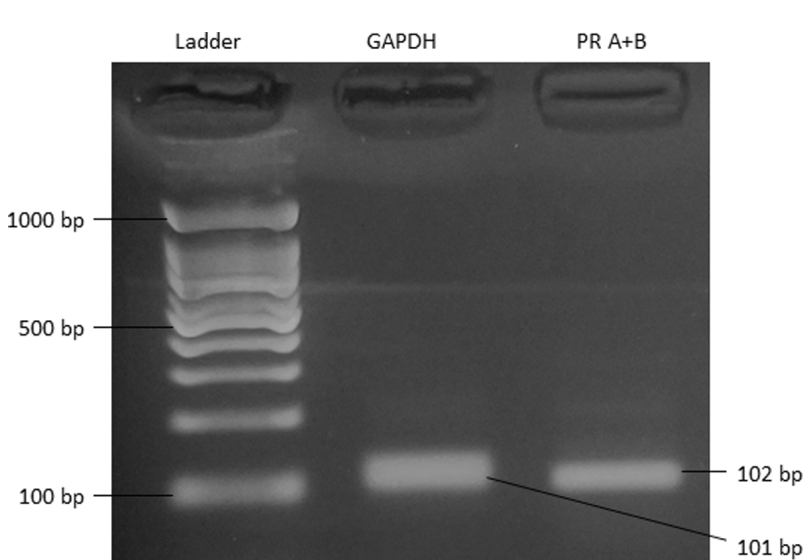

Figure 1. Expression of PR A+B mRNA in rat GSMCs. Primers aligning to a common interior sequence of PRA and PRB mRNA amplified a 102 bp product ( $\mathrm{PR} \mathrm{A}+\mathrm{B}$ ) in polymerase chain reaction of rat GSMC RNA. The identity and integrity of the product was confirmed by electrophoresis in agarose gel in the presence of ethidium bromide. $\mathrm{PR} A+\mathrm{B}$, progesterone receptor $\mathrm{A}$ and B isoforms; GSMC, gastric smooth muscle cell.

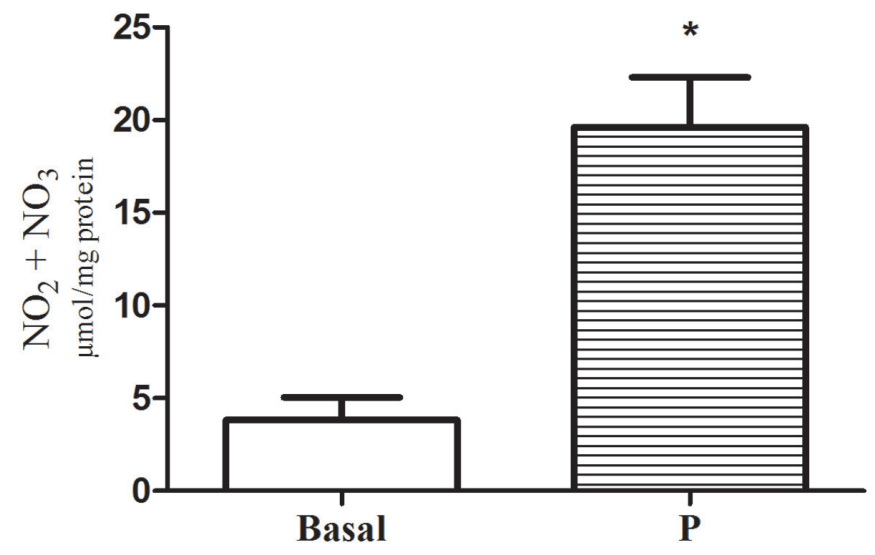

Figure 2. Effect of progesterone on NO level in single GSMCs. Total NO metabolites $\left(\mathrm{NO}_{2}^{-}\right.$and $\left.\mathrm{NO}_{3}^{-}\right)$were measured as indicators of $\mathrm{NO}$ levels. Treatment of GSMCs with progesterone $(1 \mu \mathrm{M})$ for $10 \mathrm{~min}$ significantly increased NO levels in GSMCs. Values shown are representative of at leas four independent experiments performed in triplicate. Samples were collected from 10 female rats. " $\mathrm{P}<0.05$ vs. basal. $\mathrm{NO}$, nitric oxide; $\mathrm{NO}_{2}{ }^{-}$, nitrite; $\mathrm{NO}_{3}^{-}$, nitrate; P, progesterone; GSMC, gastric smooth muscle cell.

muscle cells with a Quick-RNA MiniPrep kit (Zymo Research Corp., Irvine, CA, USA). A total of $2 \mu \mathrm{g}$ RNA from each preparation was reverse transcribed using a PrimeScript RT Master Mix (Takara Bio, Inc., Otsu, Japan) in a $10 \mu \mathrm{l}$ reaction volume. The following time and temperature profile was used for the PCR reactions: $95^{\circ} \mathrm{C}$ for $3 \mathrm{~min} ; 40$ cycles of a series consisting of $3 \mathrm{sec}$ at $95^{\circ} \mathrm{C}, 20 \mathrm{sec}$ at $60^{\circ} \mathrm{C}$ and $30 \mathrm{sec}$ at $72^{\circ} \mathrm{C}$; and a final extension for $5 \mathrm{sec}$ at $85^{\circ} \mathrm{C}$. The optimal annealing temperatures were determined empirically for each primer set. The sequences of specific primers for PR isoforms A and B were forward, 5'-TGGTTCCGCCACTCATCA-3' and reverse, 5'-TGGTCAGCAAAGAGCTGGAAG-3' (NM_022847.1); and for GAPDH (internal control) were forward, 5'-TGGTGGACCTCATGGCCTAC-3' and reverse 5'-CAGCAACTGAGGGCCTCTCT-3'. The identity and integrity of the products were confirmed by electrophoresis on $2 \%$ agarose gel containing $0.1 \mu \mathrm{g} / \mathrm{ml}$ ethidium bromide.

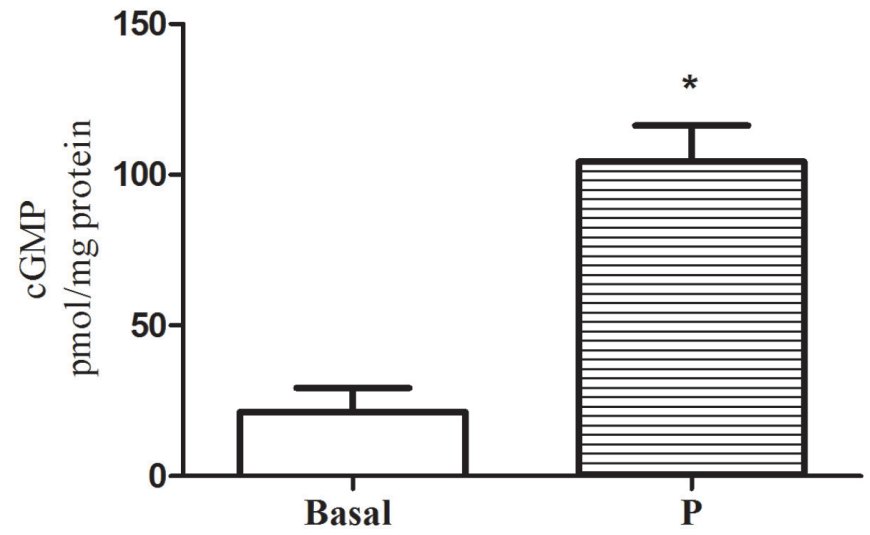

Figure 3. Effect of progesterone on cGMP formation in single GSMCs. Incubation with progesterone $(1 \mu \mathrm{M})$ for 10 min significantly increased cGMP levels in GSMCs. Values shown are representative of at least four independent experiments performed in triplicate. Samples were collected from 10 female rats. $\mathrm{P}<0.05$ vs. basal. cGMP, cyclic guanosine monophosphate; P, progesterone; GSMC, gastric smooth muscle cell.

Statistical analysis. Results are expressed as the mean \pm standard error of the mean. Statistical analysis of all experiments was performed using Prism 5.0 software (GraphPad Software, Inc., La Jolla, CA, USA). Statistical differences between two means were determined by Student's t-test. Statistical differences between multiple groups were determined using one-way analysis of variance followed by Tukey's post-hoc test. Differences were considered significant at $\mathrm{P}<0.05$.

\section{Results}

Expression of $P R$. Primers aligning to a common interior sequence of PR isoform A and B mRNA amplified a 102 bp product in RT-PCR. The identity and integrity of the product was confirmed by electrophoresis in agarose gel in the presence of ethidium bromide (Fig. 1). PCR yielded the expected product sizes (GAPDH at $101 \mathrm{bp}$ and PR A+B at $102 \mathrm{bp}$ ) based on prior Basic Local Alignment Search Tool (https://blast.ncbi.nlm. nih.gov/Blast.cgi) calculations.

Effect of progesterone on NO and cGMP formation in single GSMCs. Incubation of GSMCs with progesterone significantly increased NO and cGMP above basal levels (5.12-fold for $\mathrm{NO}_{2}{ }^{-} / \mathrm{NO}_{3}{ }^{-}$and 4.88 -fold for cGMP; $\mathrm{P}<0.05$; Figs. 2 and 3, respectively).

Effect of progesterone on ACh-induced gastric muscle contraction. Treatment with ACh lead to muscle cell contraction. More notably, treatment of GSMCs with progesterone significantly reduced the ACh-stimulated contraction of cells (66.54\% reduction; $\mathrm{P}<0.05$; Fig. 4).

Effect of the blockade of NO synthase on progesterone-induced relaxation. To investigate the role of $\mathrm{NO}$ in progesterone-induced inhibition of muscle contraction, the effect of NO synthase blocker (L-NNA) on progesterone-induced inhibition of muscle contraction was examined. It was observed that L-NNA significantly attenuated the progesterone-induced 


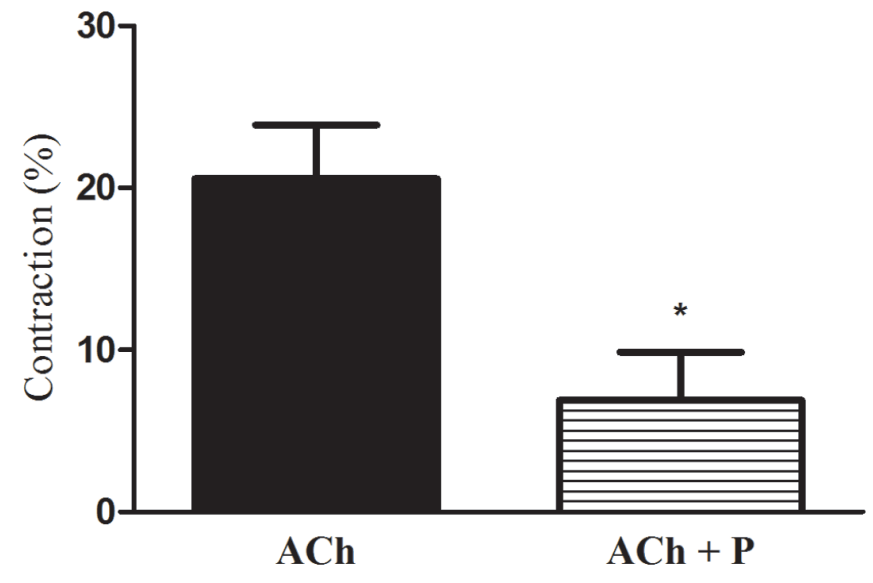

Figure 4. Effect of progesterone on ACh-induced gastric muscle contraction. Treatment of GSMCs with progesterone $(1 \mu \mathrm{M})$ for 10 min significantly reduced ACh-induced contraction. $\mathrm{n}=50$ cells from 10 different rats. ${ }^{*} \mathrm{P}<0.05$ vs. ACh. ACh, acetylcholine; GSMC, cyclic guanosine monophosphate.

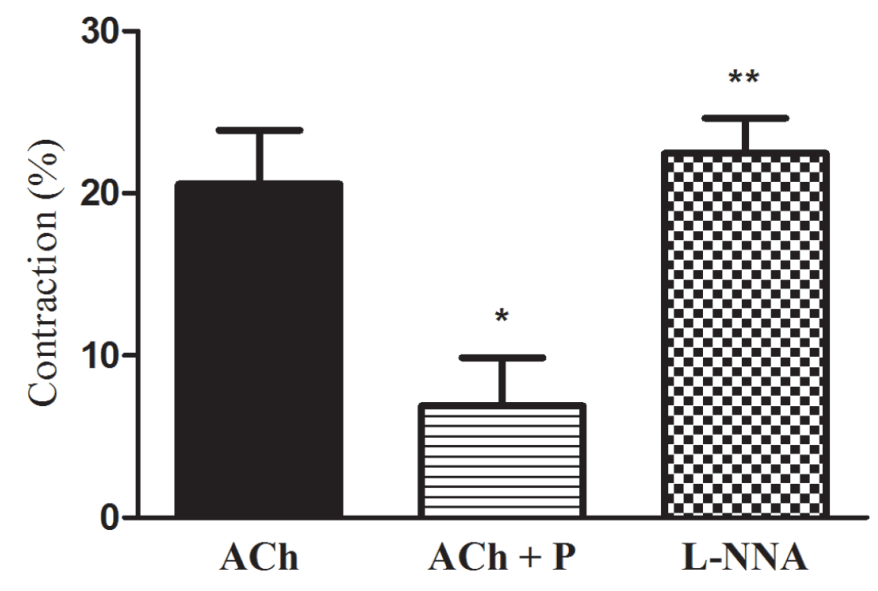

Figure 5. Effect of the blockade of nitric oxide synthase on progesterone-induced relaxation. Treatment of gastric smooth muscle cells with progesterone $(1 \mu \mathrm{M})$ for 10 min significantly reduced ACh-induced contraction. Relaxation induced by progesterone was significantly inhibited in muscle cells pre-incubated with L-NNA $(1 \mu \mathrm{M}) . \mathrm{n}=50$ cells from 10 different rats. ${ }^{*} \mathrm{P}<0.05$ vs. $\mathrm{ACh} .{ }^{* *} \mathrm{P}<0.05$ vs. $\mathrm{ACh}+\mathrm{P}$. ACh, acetylcholine; $\mathrm{P}$, progesterone; L-NNA, Nw-Nitro-L-arginine.

inhibition of muscle cell contraction (2.4-fold increase in contraction vs. ACh plus progesterone; $\mathrm{P}<0.05$; Fig. 5).

Effect of the blockade of $s G C$ on progesterone-induced relaxation. To investigate the role of cGMP in progesterone-induced inhibition of muscle contraction, the effect of sGC blocker (ODQ) on progesterone-induced inhibition of muscle contraction was examined. ODQ alleviated the progesterone-induced inhibition of muscle cell contraction $(2.5$-fold increase in contraction vs. ACh plus progesterone; $\mathrm{P}<0.05$; Fig. 6).

\section{Discussion}

The present study was designed to investigate the mechanisms involved in the progesterone-induced effect on agonist-stimulated contraction of smooth muscle cells in the stomach. The results confirmed the expression of PR in GSMCs

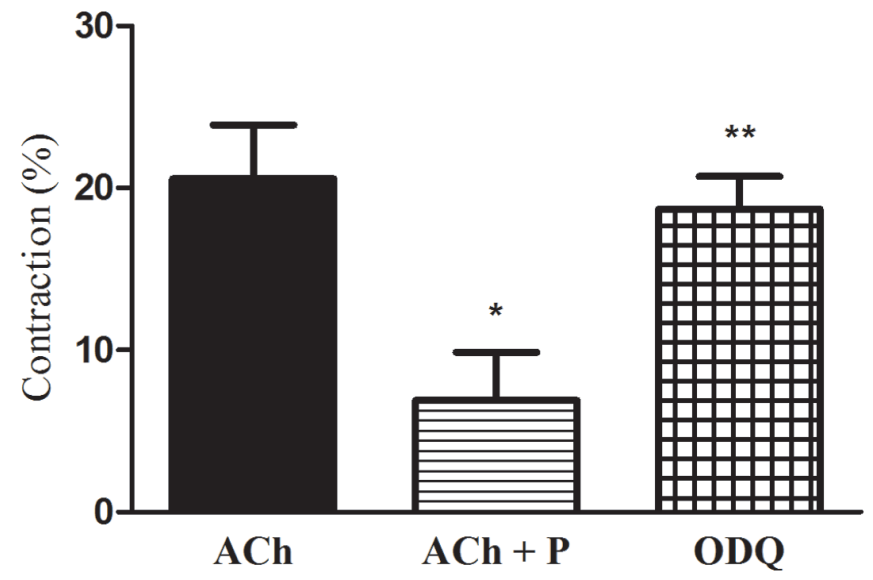

Figure 6. Effect of the blockade of soluble guanylyl cyclase on progesterone-induced relaxation. Treatment of gastric smooth muscle cells with progesterone $(1 \mu \mathrm{M})$ for 10 min significantly reduced ACh-induced contraction. Relaxation induced by progesterone was inhibited in muscle cells pre-incubated with ODQ $(1 \mu \mathrm{M}) . \mathrm{n}=50$ cells from 10 different rats. ${ }^{*} \mathrm{P}<0.05$ vs. ACh. ${ }^{* *} \mathrm{P}<0.05$ vs. ACh+P. ACh, acetylcholine; P, progesterone; ODQ, 1H-[1,2,4]Oxadiazolo[4,3-a]quinoxalin-1-one.

and suggest that progesterone inhibits agonist-induced gastric muscle contraction in rats. Such effect may be produced via stimulation of the NO/cGMP pathway. This conclusion is supported by the following observations: i) Progesterone inhibited ACh-induced contraction in single GSMCs; ii) the blockade of NO synthase abolished this effect of progesterone on gastric muscle cell contraction; and ii) the blockade of guanylyl cyclase also attenuated this effect of progesterone on gastric muscle cell contraction.

The present findings are in agreement with previous studies which reported an inhibitory action of progesterone on GI muscle contraction. For instance, Liu et al (9) identified that high doses of progesterone could decrease gastric emptying. Similarly, Coşkun's group (10) reported that chronic progesterone treatment exerted inhibitory effects on gastric emptying in conscious rats. Another study suggested that progesterone may inhibit the contractile activity of isolated gastric strips in rats (27). Furthermore, a study on gallbladder muscle cells from adult guinea pigs observed that progesterone treatment impaired the contractile response to agonist (1). There is data to suggest that high serum sex hormone concentration during pregnancy is associated with alternations in the motor activity of the GI tract, with include decreased gallbladder contractility and lower esophageal sphincter pressure, reduced gastric emptying of liquids, and reduced small intestine and colonic transit $(5,7,8,11)$. Contrary to the current findings, Xiao et al (15) reported that progesterone failed to affect colonic muscle contraction induced by $\mathrm{ACh}$ in guinea pigs. However, ACh application in their study was for $30 \mathrm{sec}$, and considering that different receptor agonists may generate both initial/transient $(<1 \mathrm{~min}) \mathrm{Ca}^{2+}$-dependent and sustained ( $>5 \mathrm{~min}$ ) $\mathrm{Ca}^{2+}$-independent contraction in GI smooth muscle cells (18), it is possible that ACh induced different signaling machinery with $30 \mathrm{sec}$ of treatment compared with the presently tested 10 -min treatment.

Treatment with progesterone for 10 min markedly inhibited the ACh-induced contraction in gastric muscle cells. It may be 
proposed that this potent hormonal effect on muscle contraction represents mostly a nongenomic action of progesterone. Nongenomic actions are defined as those occurring within 10 min of hormonal exposure in a variety of tissue types $(28,29)$. These nongenomic actions of progesterone are mostly not blocked by progesterone antagonists, which impede genomic actions of progesterone and other progestins $(15,25,30)$. Whether progesterone affects an independent non-genomic cell surface receptor distinct from the classical nuclear PR that is part of the transcription-activating superfamily or affects other membrane receptors such as $\mathrm{G}$ protein receptors remains unknown.

Previous studies have demonstrated the production of NO in isolated gastric muscle cells (31) and the role of the NO/cGMP pathway in the control of GI smooth muscle tone (18). Generally, NO induces smooth muscle relaxation mainly through the activation of $\mathrm{sGC}$ and subsequent increase in cGMP levels (18). NO can also induce relaxation via a mechanism independent of cGMP by acting on ion channels (32). The NO/cGMP pathway has been reported to be involved in the relaxation response to progesterone in various smooth muscle tissue regions including the mesenteric arteries (33), endometrium (34), myometrium (35) and pig bladder neck smooth muscle (36). The current results suggest that progesterone produces relaxation in single GSMCs via the NO/cGMP pathway, since progesterone-induced relaxations were reduced by inhibitors of NO synthase and sGC. These findings are in agreement with those obtained in pig bladder neck smooth muscle (36) and rabbit pulmonary arteries (37). The levels of cAMP and cGMP in GI smooth muscle depend on the rates of their synthesis by cyclases and degradation by PDEs $(38,39)$. In addition to degradation by phosphodiesterases, cyclic nucleotide elimination pathways include active export into the extracellular space via members of the multidrug resistance protein family (also known as the ATP-binding cassette transporter family) (40). A limitation of the current study is that focus was on the NO/cGMP pathway and the effect of progesterone on these eliminatory pathways was not examined. As an effect of progesterone on cyclic nucleotide synthesis and generation pathways can be expected, this should be investigated in future research.

Similar to the effect of progesterone on GSMCs, our group recently reported on a reduction in the contraction of female GSMCs following treatment with the sex steroid hormone estrogen, and greater activation of the NO/cGMP pathway (41). These parallel findings strengthen the hypothesis that these sex steroid hormones affect stomach muscle cell contraction.

Previous study by our group has also indicated that progesterone may rapidly affect the contractile activity of stomach muscle via inhibition of the Rho kinase pathway (17). Moreover, we recently reported lower RhoA/Rho-associated protein kinase pathway activation and lower levels of $\mathrm{MLC}_{20}$ phosphorylation in female stomach muscle cells compared with in male cells $(22,23)$. These reported differences may be related to differences in progesterone action in each sex. Future studies on progesterone may further uncover any other signaling pathways that are targeted by progesterone to induce smooth muscle relaxation.

As progesterone may target various types of cells in the stomach, studying its effect on the NO/cGMP pathway and muscle contraction in multicellular preparations as in previous studies $(27,42)$ could be difficult and non-specific. For this reason, all experiments in the present study were performed on single gastric muscle cells to avoid the effect of other non-muscle cell types. Indeed, the relatively high concentration of progesterone $(1 \mu \mathrm{M})$ required to produce relaxation of gastric smooth muscle in the present experiments was considerably greater than the picomolar-nanomolar levels of circulating steroids in the plasma under normal (non-pregnant) physiological conditions (43). However, the concentration tested here agrees with the micromolar (0.1-10 $\mu \mathrm{M})$ concentrations of progesterone required to elicit significant relaxation in smooth muscle of the GI tract in vitro $(25,26)$. In future studies, investigating the effect of progesterone on GSMCs by constructing dose-response curves for a wide concentration range would strengthen the present findings.

In conclusion, it was indicated in the present study that progesterone reduced $\mathrm{ACh}$-induced contraction in rat GSMCs and that this progesterone-induced effect may be mediated by the NO/cGMP pathway. Further understanding of the role of progesterone and other sex hormones in modulating the normal physiological and abnormal functions of the GI tract may enable more effective and sex-dependent treatments for many of the known GI disturbances.

\section{Acknowledgements}

Not applicable.

\section{Funding}

The present work was supported by Jordan University of Science and Technology, Irbid, Jordan (grant no. 20150178).

\section{Availability of data and materials}

The datasets used and/or analyzed during the current study are available from the corresponding author on reasonable request.

\section{Authors' contributions}

Conception and design of the study were performed by OAA. Acquisition of data and drafting of the manuscript were performed by OAA, AGM and AAO. Analysis and interpretation of data were performed by OAA, AGM, AAO, ANA, MSN and MoAA. Critical revision of the manuscript for important intellectual content was performed by OAA, AAO, MaAA and RAA. All authors read and approved the final version of the manuscript.

\section{Ethics approval and consent to participate}

The study protocol was approved by the Animal Care and Use Committee of Jordan University of Science and Technology, Irbid, Jordan.

\section{Patient consent for publication}

Not applicable. 


\section{Competing interests}

The authors declare that they have no competing interests.

\section{References}

1. Chen Q, Chitinavis V, Xiao Z, Yu P, Oh S, Biancani P and Behar J: Impaired $G$ protein function in gallbladder muscle from progesterone-treated guinea pigs. Am J Physiol 274: G283-G289, 1998.

2. Chen Q, Xiao ZL, Biancani P and Behar J: Downregulation of Galphaq-11 protein expression in guinea pig antral and colonic circular muscle during pregnancy. Am J Physiol 276: G895-G900, 1999.

3. Datta S, Hey VM and Pleuvry BJ: Effects of pregnancy and associated hormones in mouse intestine, in vivo and in vitro. Pflugers Arch 346: 87-95, 1974.

4. Ryan JP and Pellecchia D: Effect of progesterone pretreatment on guinea pig gallbladder motility in vitro. Gastroenterology 83: 81-83, 1982.

5. Ryan JP and Bhojwani A: Colonic transit in rats: Effect of ovariectomy, sex steroid hormones, and pregnancy. Am J Physiol 251: G46-G50, 1986.

6. Everson GT, McKinley C, Lawson M, Johnson M and Kern F Jr: Gallbladder function in the human female: Effect of the ovulatory cycle, pregnancy, and contraceptive steroids. Gastroenterology 82: 711-719, 1982.

7. Brock-Utne JG, Dow TG, Dimopoulos GE, Welman S, Downing JW and Moshal MG: Gastric and lower oesophageal sphincter (LOS) pressures in early pregnancy. Br J Anaesth 53: 381-384, 1981

8. Parkman HP, Wang MB and Ryan JP: Decreased electromechanical activity of guinea pig circular muscle during pregnancy. Gastroenterology 105: 1306-1312, 1993.

9. Liu CY, Chen LB, Liu PY, Xie DP and Wang PS: Effects of progesterone on gastric emptying and intestinal transit in male rats. World J Gastroenterol 8: 338-341, 2002.

10. Coşkun T, Sevinç A, Tevetoğlu I, Alican I, Kurtel H and Yeğen BC: Delayed gastric emptying in conscious male rats following chronic estrogen and progesterone treatment. Res Exp Med 195: 49-54, 1995

11. Ryan JP: Effect of pregnancy on intestinal transit: Comparison of results using radioactive and non-radioactive test meals. Life Sci 31: 2635-2640, 1982.

12. Martinez F, Tesarik J, Martin CM, Soler A and Mendoza C: Stimulation of tyrosine phosphorylation by progesterone and its 11-OH derivatives: Dissection of a $\mathrm{Ca}^{2+}$-dependent and a $\mathrm{Ca}^{2+}$-independent mechanism. Biochem Biophys Res Commun 255: 23-27, 1999.

13. Luconi M, Krausz C, Barni T, Vannelli GB, Forti G and Baldi E: Progesterone stimulates p42 extracellular signal-regulated kinase (p42erk) in human spermatozoa. Mol Hum Reprod 4: 251-258, 1998

14. Metherall JE, Waugh $\mathrm{K}$ and $\mathrm{Li} \mathrm{H}$ : Progesterone inhibits cholesterol biosynthesis in cultured cells. Accumulation of cholesterol precursors. J Biol Chem 271: 2627-2633, 1996.

15. Xiao ZL, Cao W, Biancani P and Behar J: Nongenomic effects of progesterone on the contraction of muscle cells from the guinea pig colon. Am J Physiol Gastrointest Liver Physiol 290: G1008-G1015, 2006.

16. Xiao ZL, Biancani P and Behar J: Effects of progesterone on motility and prostaglandin levels in the distal guinea pig colon. Am J Physiol Gastrointest Liver Physiol 297: G886-G893, 2009.

17. Al-Shboul O, Mustafa A and Al-hashimi F: Non-genomic effects of progesterone on Rho kinase II in rat gastric smooth muscle cells. J Smooth Muscle Res 49: 55-62, 2013.

18. Murthy KS: Signaling for contraction and relaxation in smooth muscle of the gut. Annu Rev Physiol 68: 345-374, 2006.

19. Francis SH and Corbin JD: Cyclic nucleotide-dependent protein kinases: Intracellular receptors for cAMP and cGMP action. Crit Rev Clin Lab Sci 36: 275-328, 1999.

20. Denninger JW and Marletta MA: Guanylate cyclase and the NO/cGMP signaling pathway. Biochim Biophys Acta 1411: 334-350, 1999 .

21. Somlyo AP and Somlyo AV: $\mathrm{Ca}^{2+}$ sensitivity of smooth muscle and nonmuscle myosin II: Modulated by G proteins, kinases, and myosin phosphatase. Physiol Rev 83: 1325-1358, 2003.
22. Al-Shboul O: The role of the RhoA/ROCK pathway in gender-dependent differences in gastric smooth muscle contraction. J Physiol Sci 66: 85-92, 2016.

23. Al-Shboul OA, Al-Dwairi AN, Alqudah MA and Mustafa AG: Gender differences in the regulation of MLC20 phosphorylation and smooth muscle contraction in rat stomach. Biomed Rep 8: 283-288, 2018

24. Al-Shboul O and Mustafa A: Effect of oxidative stress on Rho kinase II and smooth muscle contraction in rat stomach. Can J Physiol Pharmacol 93: 405-411, 2015.

25. Bielefeldt K, Waite L, Abboud FM and Conklin JL: Nongenomic effects of progesterone on human intestinal smooth muscle cells. Am J Physiol 271: G370-G376, 1996.

26. Gill RC, Bowes KL and Kingma YJ: Effect of progesterone on canine colonic smooth muscle. Gastroenterology 88: 1941-1947, 1985.

27. Wang F, Zheng TZ, Li W, Qu SY and He DY: Action of progesterone on contractile activity of isolated gastric strips in rats. World J Gastroenterol 9: 775-778, 2003.

28. Sager G, Ørbo A, Jaeger R and Engström C: Non-genomic effects of progestins--inhibition of cell growth and increased intracellular levels of cyclic nucleotides. J Steroid Biochem Mol Biol 84: 1-8, 2003.

29. Blackmore PF, Neulen J, Lattanzio F and Beebe SJ: Cell surface-binding sites for progesterone mediate calcium uptake in human sperm. J Biol Chem 266: 18655-18659, 1991.

30. Minshall RD, Pavenik D, Browne DL and Hermsmeyer K: Nongenomic vasodilator action of progesterone on primate coronary arteries. J Appl Physiol (1985) 92: 701-708, 2002.

31. Grider JR, Murthy KS, Jin JG and Makhlouf GM: Stimulation of nitric oxide from muscle cells by VIP: Prejunctional enhancement of VIP release. Am J Physiol 262: G774-G778, 1992.

32. Perez-Zoghbi JF, Bai Y and Sanderson MJ: Nitric oxide induces airway smooth muscle cell relaxation by decreasing the frequency of agonist-induced Ca2+ oscillations. J Gen Physiol 135: 247-259, 2010.

33. Chan HY, Yao X, Tsang SY, Chan FL, Lau CW and Huang Y: Different role of endothelium/nitric oxide in 17beta-estradioland progesterone-induced relaxation in rat arteries. Life Sci 69: 1609-1617, 2001.

34. Khorram O and Han G: Influence of progesterone on endometrial nitric oxide synthase expression. Fertil Steril 91: 2157-2162, 2009.

35. Bulbul A, Yağci A, Altunbas K, Sevimli A, Celik HA, Karadeniz A and Akdağ E: The role of nitric oxide in the effects of ovarian steroids on spontaneous myometrial contractility in rats. Theriogenology 68: 1156-1168, 2007.

36. Fernandes VS, Ribeiro AS, Martínez-Sáenz A, Blaha I, Serrano-Margüello D, Recio P, Martínez AC, Bustamante S, Vázquez-Alba D, Carballido J, et al: Underlying mechanisms involved in progesterone-induced relaxation to the pig bladder neck. Eur J Pharmacol 723: 246-252, 2014.

37. Li HF, Zheng TZ, Li W, Qu SY and Zhang CL: Effect of progesterone on the contractile response of isolated pulmonary artery in rabbits. Can J Physiol Pharmacol 79: 545-550, 2001.

38. Rybalkin SD, Yan C, Bornfeldt KE and Beavo JA: Cyclic GMP phosphodiesterases and regulation of smooth muscle function. Circ Res 93: 280-291, 2003.

39. Al-Shboul O: Contraction and relaxation signaling in gastrointestinal smooth muscle. EC Gastroenterol Dig Syst 5: 315-321, 2018.

40. Sager G: Cyclic GMP transporters. Neurochem Int 45: 865-873, 2004.

41. Al-Shboul OA, Nazzal MS, Mustafa AG, Al-Dwairi AN, Alqudah MA, Abu Omar A, Alfaqih MA and Alsalem MI: Estrogen relaxes gastric muscle cells via a nitric oxide- and cyclic guanosine monophosphate-dependent mechanism: A sex-associated differential effect. Exp Ther Med 16: 1685-1692, 2018.

42. Ryan JP, Bhojwani A and Wang MB: Effect of pregnancy on gastric motility in vivo and in vitro in the guinea pig. Gastroenterology 93: 29-34, 1987.

43. Zou S, Li X, Feng Y, Sun S, Li J, Egecioglu E, Billig H and Shao R: Comparison of the diagnostic values of circulating steroid hormones, VEGF-A, PIGF, and ADAM12 in women with ectopic pregnancy. J Transl Med 11: 44, 2013. 